\title{
Mechanical, structural and tribological properties of superaustenitic stainless steel submitted at solution heat treatment
}

\author{
Fabiana Cristina Nascimento Borges ${ }^{1}$, Willian Rafael de Oliveira ${ }^{1}$,
} Jonas Kublitski ${ }^{1}$

\author{
${ }^{1}$ Laboratório de Espectroscopia Mössbauer - DEFIS/UEPG CP: 84030-900, Ponta Grossa, PR \\ e-mail: fabianacristina@uepg.br
}

\section{RESUMO}

O aço inoxidável superasutenítico apresenta diversas aplicações tecnológicas, principalmente em ambientes corrosivos. A precipitação de diferentes fases pode alterar algumas de suas propriedades mecânicas. Tais alterações afetam vários fatores, incluindo a vida útil do material diante de condições de trabalho adversas. Neste estudo, medidas de Indentação Instrumentada, Tribologia e Difração de Raios X (DRX) foram utilizadas para avaliar possíveis alterações em regiões próximas à superfície em amostras tratadas termicamente. Os parâmetros analisados foram: dureza e módulo de elasticidade, coeficiente de atrito e alterações estruturais na célula unitária nas fases identificadas. Os resultados foram comparados com aço austenítico comum da família AISI 304. A presença das fases $\sigma$ (grupo espacial P42mnm) e austenita- $\gamma$ (grupo espacial Fm3m) foram detectadas. Os dados analisados indicaram que a presença da fase intermetálica $\sigma$ contribuiu para pequenas alterações na dureza em regiões próximas à superfície e no coeficiente de atrito. Para regiões mais profundas (bulk) as propriedades analisadas foram semelhantes aos aços inoxidáveis comerciais.

Palavras-chave: aço austenítico, aço superaustenitico, refinamento Rietveld.

\begin{abstract}
The superaustenitic stainless steel presents several technological applications, mainly in corrosive environments. The different phase precipitation might alter some of its mechanical properties. Such alterations affect several factors, including the working life of the material under adverse working conditions. In this study, Instrumented Indentation techniques, Tribology and X-ray diffraction (XRD) were used to evaluate alterations in regions close to the surface. The parameters analyzed were: hardness and elastic modulus (instrumented indentation), friction coefficient (tribology) and structural alterations of the unit cell of the identified phases (XRD - Rietveld Refinement). All properties analyzed were compared with those of common austenitic steel. The presence of $\sigma$-phase (space group P42mnm) and $\gamma$-austenite (space group Fm $3 \mathrm{~m}$ ) were detected. Data analyzed indicated that the presence of $\sigma$-phase caused small alteration in properties such as hardness in regions close to the surface. In the regions farther from the surface (material bulk) data can be compared to that of conventional austenitic steel.
\end{abstract}

Keywords: austenitic steel, superaustenitic steel, Rietveld refinement.

\section{INTRODUCTION}

The study of mechanical properties is extremely important to predict the material behavior when facing different conditions of use (environment, stress, temperature, among others). When it comes to the study of superaustenitic steel, the investigation of mechanical, structural and tribological properties is indicated to better understand the mechanisms which result in modification of different physical and mechanical properties, due to the presence of intermetallic phases. Superaustenitic steel in particular presents high resistance to pitting corrosion, which is due to the high content of $\mathrm{Cr}$, Mo and the PREN number (Pitting Resistance Equivalent Number) equivalent to $\mathrm{PREN}=\mathrm{xx} \% \mathrm{Cr}+3.3 \% \mathrm{Mo}+16 \% \mathrm{~N}$. Data in the literature indicates that the superaustenitic steel presents a PREN number varying between 28.3 and 64.3 [1], [2]. Due to high resistance to corrosion, this steel is called superaustenitic presenting some particularities of high molybdenum, chrome, nickel, nitrogen and manganese content in its chemical composition. Elements such as Mo, Ni and 
$\mathrm{Cr}$ favor the precipitation of secondary phases. In terms of microstructure, different intermetallic phases and carbides can be identified. Carbides of the kind $\mathrm{M}_{23} \mathrm{C}_{6}$ and $\mathrm{M}_{6} \mathrm{C}$ are formed due to the high presence of carbon, and the most common intermetallic phases are: sigma phase $(\sigma)$, Laves and Chi phase $(\chi)[3]$, [4], many times studied from TTT diagrams. Several works in the literature aimed to investigate the presence of such phases and their effects []ㅡ, []], []].

This study presents a set of complementary data to the research started at Unicamp [] ], [9], [10] coordinated by Prof. Dr. Paulo R. Mei and collaborators in the ASTMA 744 Gr. CN3MN steel. Profiles of hardness, elastic modulus and nanoscratch were studied through instrumented indentation. Tribological (friction coefficient) and structural properties also complemented this study.

\section{MATERIALS AND METHODS}

\subsection{Materials}

The superaustenitic steel ASTM A 744 Gr. CN3MN presents chemical composition (percentage in weight \%): 0.019 C, 0.88 Mn, 0.69 Si 0.02 P, 0.006 S, 21.98 Cr, 24.84 Ni, 6.35 Mo, 0.010 C, 0.23 N and Fe. Samples were submitted, in previous studies, to solubilization thermal treatment at $1200^{\circ} \mathrm{C}$ (sample A) and $1240^{\circ} \mathrm{C}$ (sample B) with water cooling. The objective was to dilute precipitates formed during the solidification process [],$[\underline{9]},[\underline{10}]$.

\subsection{Methods}

For the instrumented indentation, tribology and Rietveld refinement analyses, samples were embedded using cold resin, and later on prepared with mechanical polishing up to 1/4 diamond paste.

Nanomechanical properties (hardness and elastic modulus) were analyzed at depths near the surface using a diamond indenter (Berkovich). Loads of $400 \mathrm{mN}$ were used. Nanoscratch tests were carried out using increasing loads from 0 to $400 \mathrm{nM}$ and the scratch length was programmed to $1 \mathrm{~mm}$. The penetration profile indenter-surface was monitored before, during and after the scratch.

Tribological tests (room temperature) were carried using a WC ball (Co) with $6 \mathrm{~mm}$ diameter, $5.0 \mathrm{~N}$ load and $9.0 \mathrm{~m}$ distance corresponding to $2.25 \times 10^{3}$ cycles. Three scratches were made on the surface of each sample.

X-ray data (XRD) was collected at the interval $20^{\circ} \leq 2 \theta \leq 100^{\circ}$ using $\operatorname{CuK}_{\alpha}(\lambda=1.5406 \AA$ ) radiation with 5 s counting. Structural data were analyzed for surface samples. Crystalline plans corresponding to the phases analyzed were indexed using the Joint Committee on Powder Diffraction Standards (JCPDS) data basis. Structural variations were assessed using the Rietveld Refinement.

\section{RESULTS}

Figure 1 presents the X-ray diffractograms at the interval $30^{\circ} \leq 2 \theta \leq 100^{\circ}$. In both cases, a typical austenitic structure was detected, identified by the PCPDS card 33-0397. The reflections $(111)_{\gamma},(200)_{\gamma},(220)_{\gamma},(311)_{\gamma}$, and $(222)_{\gamma}$ were identified in both samples. The cubic symmetry with the space group Fm $3 \mathrm{~m}$ of the austenitic phase was confirmed using the Rietveld Refinement from XRD data. The lattice parameters found in samples A and B were, respectively: $\mathrm{a}_{\mathrm{A}}=3.5912$ (2) $\AA$ and $\mathrm{a}_{\mathrm{B}}=3.5918$ (4) $\AA$. 




$2 \theta$ (Degree)

Figure 1: Identification of $\gamma$-phase and $\sigma$-phase present in samples submitted at solution heat treatment $\left(1200^{\circ} \mathrm{C}\right.$ and $\left.1240^{\circ} \mathrm{C}\right)$

Figure 1 at the interval $37^{\circ} \leq 2 \theta \leq 56^{\circ}$ marked by dashed line indicates the presence of $\sigma$-phase in the treated sample $1240^{\circ} \mathrm{C}$. This region was enlarged inset in Figure 1 in order to better visualize above. The reflections $(330)_{\sigma},(411)_{\sigma},(311)_{\sigma}$ and $(313)_{\sigma}$ corresponding to the $\sigma$ intermetallic phase, space group $\mathrm{P} 4_{2} / \mathrm{mnm}$ were identified presenting the following lattice parameters: $\mathrm{a}=8.721(3) \AA$ and $\mathrm{c}=4.553(1) \AA$. The $\chi$ phase and $\mathrm{M}_{6} \mathrm{C}$ carbides were detected in previous studies [8]. According to literature [8] the volume fraction of $\sigma$ phase was approximately $2 \%$ and $7 \%$ for samples A and B respectively.

The microstructure and mechanical properties (HB-hardness) before heat treatment and for different heat treatment temperatures were investigated by Ritorni and co authors [9]. The results indicated that the hardness changed with heat treatment above $1200^{\circ} \mathrm{C}$ as a result of the fine distribution precipitates formed during cooling [9]. In this work, the nano hardness variation in samples A and B are presented in Figure 2. The superaustenitic stainless steel presented hardness around 5.8 GPa in regions close to the surface (contact surface $<200 \mathrm{~nm}$ ). On average, samples (A and B) presented very close hardness values on the surface, indicating that the presence of other phases did not alter the material superficial hardness. The hardness at depths higher than $2000 \mathrm{~nm}$ (bulk) is not shown in Figure 2 as it was evaluated in a previous study [11] in which it presented value close to $2.8 \mathrm{GPa}$. This region was compared to the hardness of a commercial austenitic stainless steel AISI 304 [12] which presented hardness (bulk) around $3.5 \mathrm{GPa}$. It can be seen from Figure 2 that the values present a significant dispersion band in regions very close to the surface. This behavior is common in instrumented indented measurements as they reflect the surface effects [13]. 


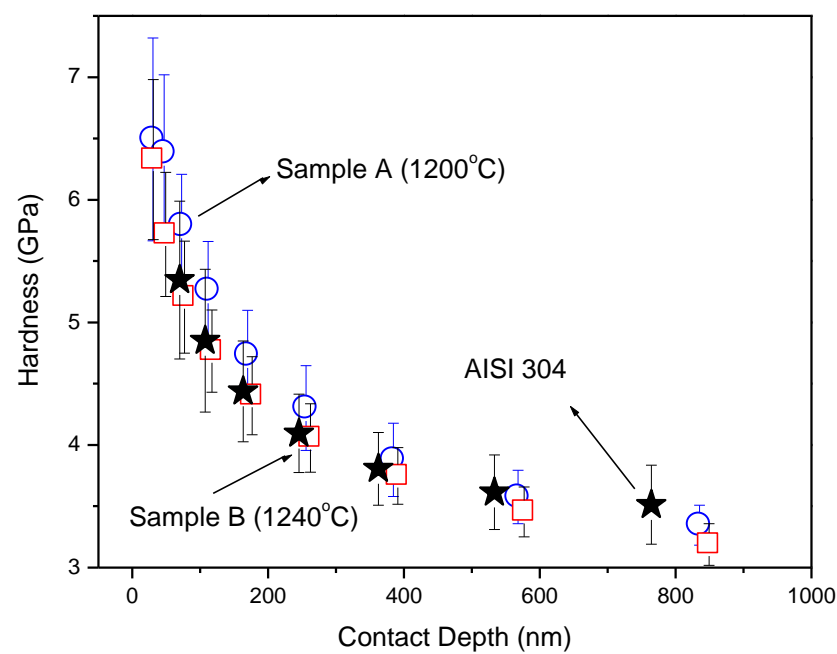

Figure 2: Comparison of hardness profile of the superaustenitic steel treated at $1200^{\circ} \mathrm{C}$ and $1240^{\circ} \mathrm{C}$ and the austenitic steel AISI 304.

The presence of a phase $\sigma$ did not alter the superaustenitic steel elastic modulus value, Figure 3, when compared to the common commercial steel [14], presenting a value of approximately $210 \mathrm{GPa}$. In Figure 3, the variation of the elastic modulus and hardness after the solubilization thermal treatments are shown.

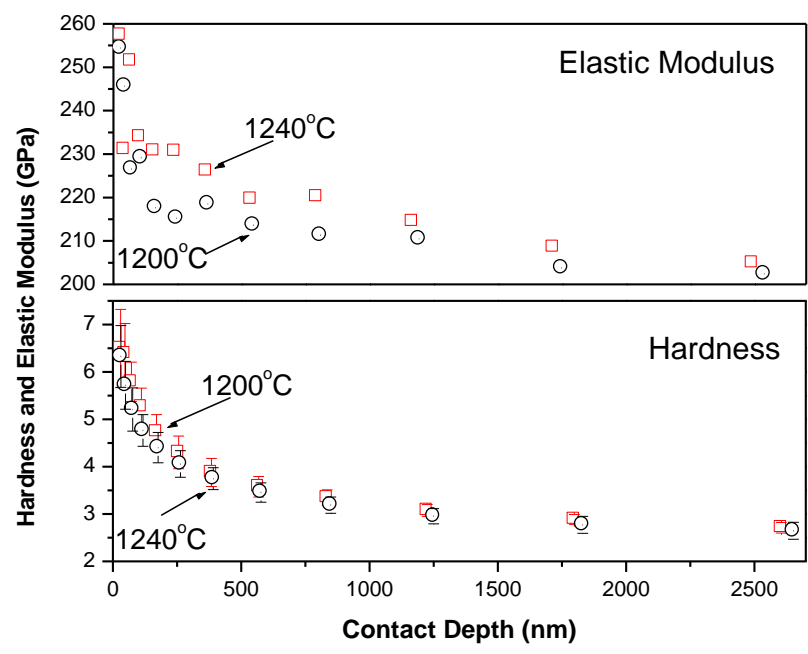

Figure 3: Variation of hardness and elastic modulus in samples A and B.

The surface profile was evaluated with nanoscratch measurements in both samples. Results were very similar not indicating significant difference as a function of the solubilization treatment temperatures. Sample $\mathrm{B}$, the highest treatment temperature, (Figure 4a) was chosen as the representative of the superaustenitic steel in this work and compared to the austenitic steel AISI 304 (Figure 4b).

Higher fluctuation was observed in the curves during and after the scratch in the reference sample, (Fig. 4b). This behavior, typical of steel, indicates an irregular surface, which is not in this case directly related to the presence of other phases, once there were no significant alterations in other properties, such as hardness. The indenter penetration depth is very alike in both steel samples (superaustenitic - Figure 4a and austenitic - Figure 4b) which is in agreement with the closeness in hardness values, Figure 2. 

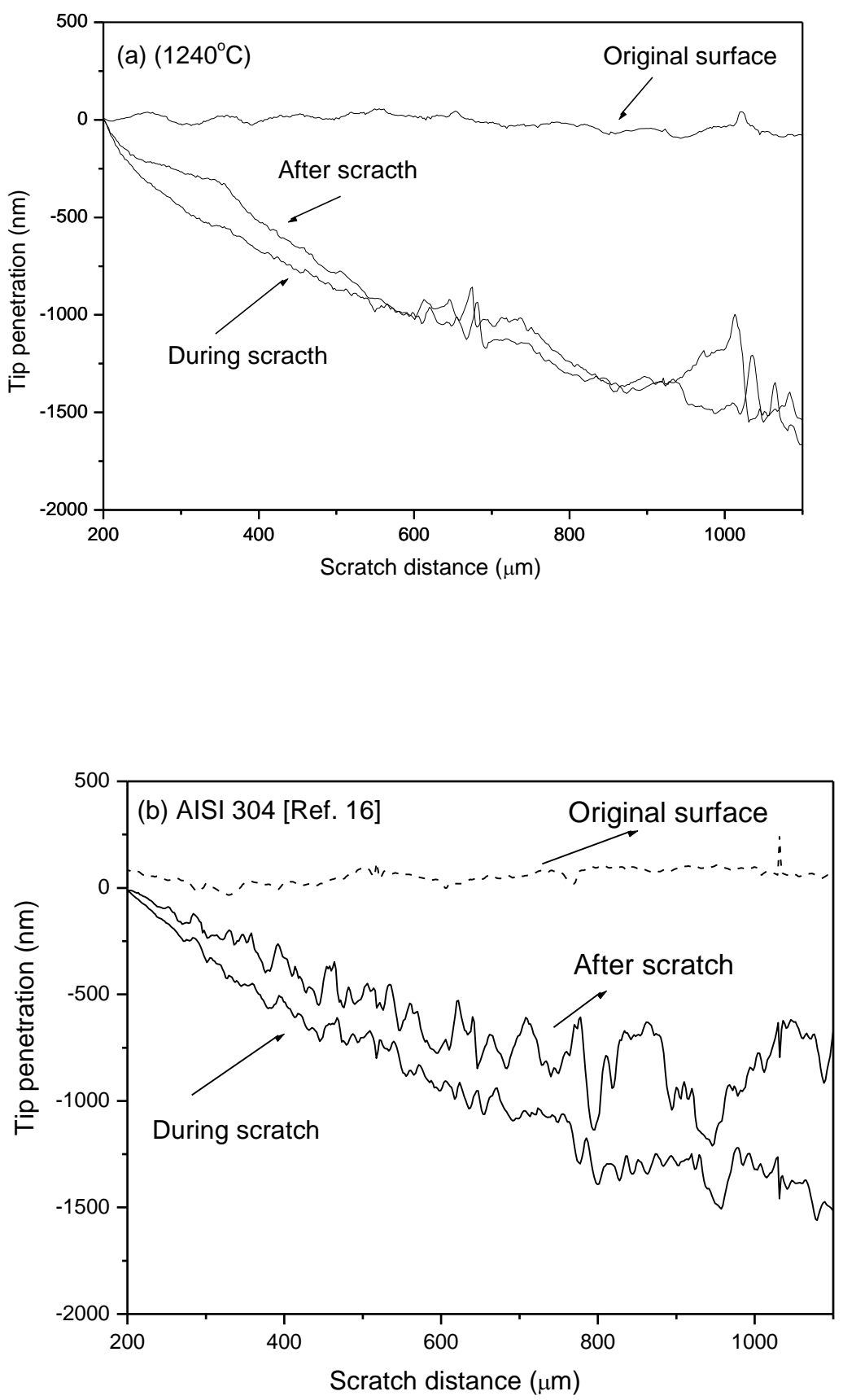

Figure 4: Evaluation of the surface profile, using nanoscratch in: (a) superaustenitic steel sample and (b) austenitic steel AISI 304.

The presence of a phase $\sigma$ presented more effect in the friction coefficient analysis, Figure 5. A difference of approximately $5.8 \%$ could be observed in the friction coefficient values between samples A and B. The comparative results are presented in Table 1. 


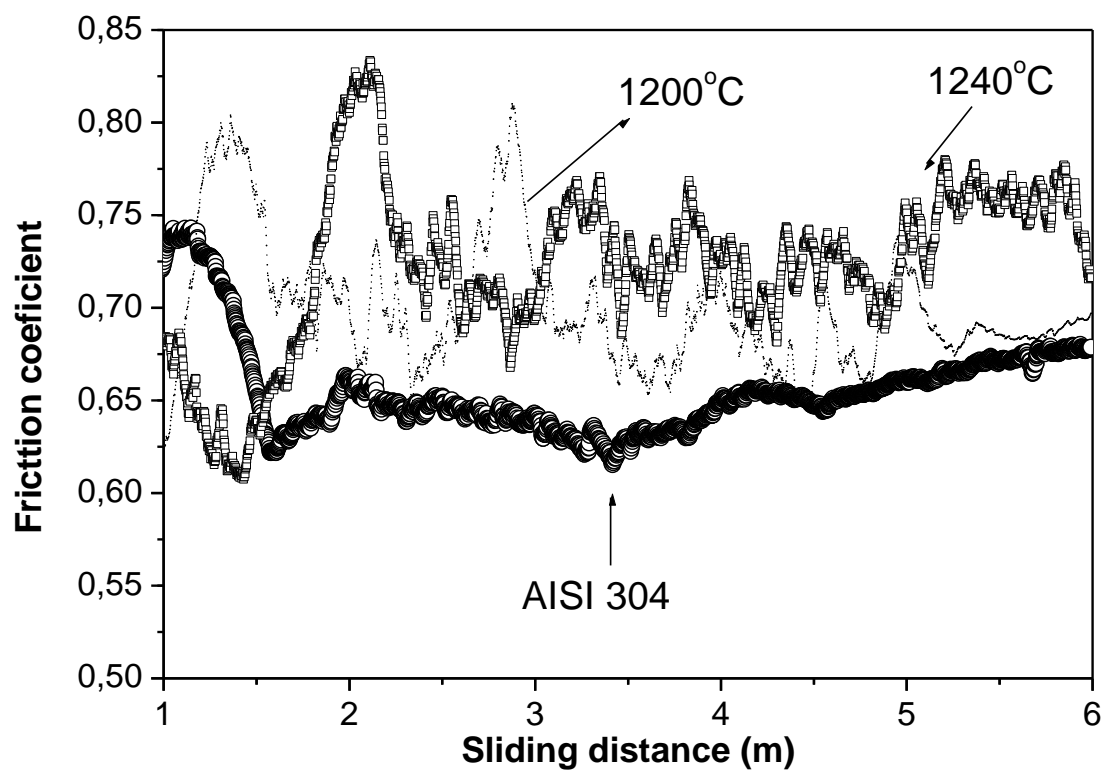

Figure 5: Steel AISI 304, and superaustenitic steel (samples A and B) friction coefficient.

Table 1: Comparison of mechanical and structural properties of superaustenitic steel and common austenistic steels.

\begin{tabular}{|c|c|c|c|c|c|c|c|}
\hline \multicolumn{8}{|c|}{ Mechanical and tribological properties } \\
\hline \multicolumn{2}{|l|}{ Steel } & $\begin{array}{c}\text { Hardness }(\mathrm{GPa}) \\
\left(\mathrm{h}_{\mathrm{c}} \cong 115 \mathrm{~nm}\right)\end{array}$ & \multicolumn{2}{|c|}{$\begin{array}{l}\text { Elastic modu- } \\
\operatorname{lus(GPa)}\end{array}$} & \multicolumn{2}{|c|}{$\begin{array}{c}\text { Friction coeffi- } \\
\text { cient }\end{array}$} & Reference \\
\hline \multicolumn{2}{|l|}{ AISI 304} & 5.0 & \multicolumn{2}{|c|}{$\sim 200$} & \multicolumn{2}{|c|}{0.60} & {$[\underline{15}]$} \\
\hline \multicolumn{2}{|l|}{ AISI 316} & 4.0 & \multicolumn{2}{|c|}{$\sim 200$} & \multicolumn{2}{|c|}{0.60} & --- \\
\hline \multicolumn{2}{|l|}{ AISI 304L } & 4.2 & \multicolumn{2}{|c|}{$\sim 200$} & \multicolumn{2}{|c|}{0.60} & --- \\
\hline \multicolumn{2}{|l|}{ AISI 316L } & 4.0 & \multicolumn{2}{|c|}{$\sim 200$} & \multicolumn{2}{|c|}{---} & {$[16,17]$} \\
\hline \multicolumn{2}{|c|}{ *Sample A $\left(1200^{\circ} \mathrm{C}\right)$} & 5.3 & \multicolumn{2}{|c|}{$\sim 210$} & \multicolumn{2}{|c|}{0.68} & --- \\
\hline \multicolumn{2}{|c|}{ * Sample B $\left(1240^{\circ} \mathrm{C}\right)$} & 4.8 & \multicolumn{2}{|c|}{$\sim 210$} & \multicolumn{2}{|c|}{0.72} & --- \\
\hline \multicolumn{8}{|c|}{ Structural properties } \\
\hline Steel & Phases & \multicolumn{2}{|c|}{ Lattice parameters $(\AA ̊)$} & \multicolumn{2}{|c|}{ Space group } & JCPDS & Reference \\
\hline AISI 304 & $\gamma_{\mathrm{fcc}}$ & \multicolumn{2}{|c|}{$\mathrm{a}=\mathrm{b}=\mathrm{c}=3.5918(1) \AA$} & \multicolumn{2}{|c|}{ Fm-3m } & 33-0397 & {$[\underline{15]}$} \\
\hline AISI 316 & $\gamma_{\mathrm{fcc}}$ & \multicolumn{2}{|c|}{$\mathrm{a}=\mathrm{b}=\mathrm{c}=3.5935(1) \AA$} & \multicolumn{2}{|c|}{ Fm-3m } & 33-0397 & --- \\
\hline AISI 304L & $\gamma_{\mathrm{fcc}}$ & \multicolumn{2}{|c|}{$\mathrm{a}=\mathrm{b}=\mathrm{c}=3.5822(4) \AA$} & \multicolumn{2}{|c|}{ Fm-3m } & 33-0397 & --- \\
\hline AISI 316L & $\gamma_{\mathrm{fcc}}$ & \multicolumn{2}{|c|}{$\mathrm{a}=\mathrm{b}=\mathrm{c}=3.5822(2) \AA$} & \multicolumn{2}{|c|}{ Fm-3m } & 33-0397 & {$[\underline{16]}$} \\
\hline $\begin{array}{ll}\text { Sample } & A \\
\left(1200^{\circ} \mathrm{C}\right) & \end{array}$ & $\begin{array}{l}\gamma_{\mathrm{fcc}} \\
\chi_{\mathrm{bcc}} \\
\sigma_{\mathrm{bct}}\end{array}$ & $\mathrm{a}=\mathrm{b}=\mathrm{c}=3.572$ & (3) $\AA$ & \multicolumn{2}{|c|}{$\begin{array}{c}\text { Fm-3m } \\
\text { I43mSA } \\
\text { P42 } \\
\text { mnm }\end{array}$} & $33-0397$ & --- \\
\hline $\begin{array}{ll}\text { Sample } & \text { B } \\
\left(1240^{\circ} \mathrm{C}\right) & \end{array}$ & $\begin{array}{l}\gamma_{\mathrm{fcc}} \\
\chi_{\mathrm{bcc}} \\
\sigma_{\mathrm{bct}}\end{array}$ & $\mathrm{a}=\mathrm{b}=\mathrm{c}=3.552$ & (8) $\AA$ & $\begin{array}{l}\mathrm{F} 1 \\
\mathrm{I} 4 \\
\mathrm{P} 4 \\
\end{array}$ & $\begin{array}{l}-3 \mathrm{~m} \\
\mathrm{nSA} \\
\mathrm{mnm}\end{array}$ & $33-0397$ & --- \\
\hline
\end{tabular}


Images presented in Figure 6(a-f) reveal the impression of tribological tests carried out on the superaustenitic steel surface of samples A and B. The same characteristics observed in sample B were seen in the reference sample (AISI 304).

The tests comprised three scratches, as it can be seen from the optical microscopy shown in Figure 6a (sample A). From the three scratches presented in this image, the first scratch (from top to bottom, interrupted line) was chosen to discuss some interesting details. In Figure 6b (sample A), some flaws can be seen which correspond to a small portion of material taken out during the tests. This characteristic, in the proportion presented in this figure is common in steel, not altering the material friction coefficient values.

In Figures 6c (sample A) and 6d (sample B) details of the wider end of the scratch (higher loads) are observed. Comparing these figures, it can be seen that Figure $6 \mathrm{~d}$ presented a wider scratch at one end, probably due to the lower hardness value (Table 1). All scratches presented similar characteristics. The difference in color refers to the interaction between the surface and deeper regions of the sample, not indicating interaction with other phases in this region. In Figure $6 \mathrm{~d}$ (sample A) and $6 \mathrm{f}$ (sample B) the scratch central region is observed. No difference was observed.

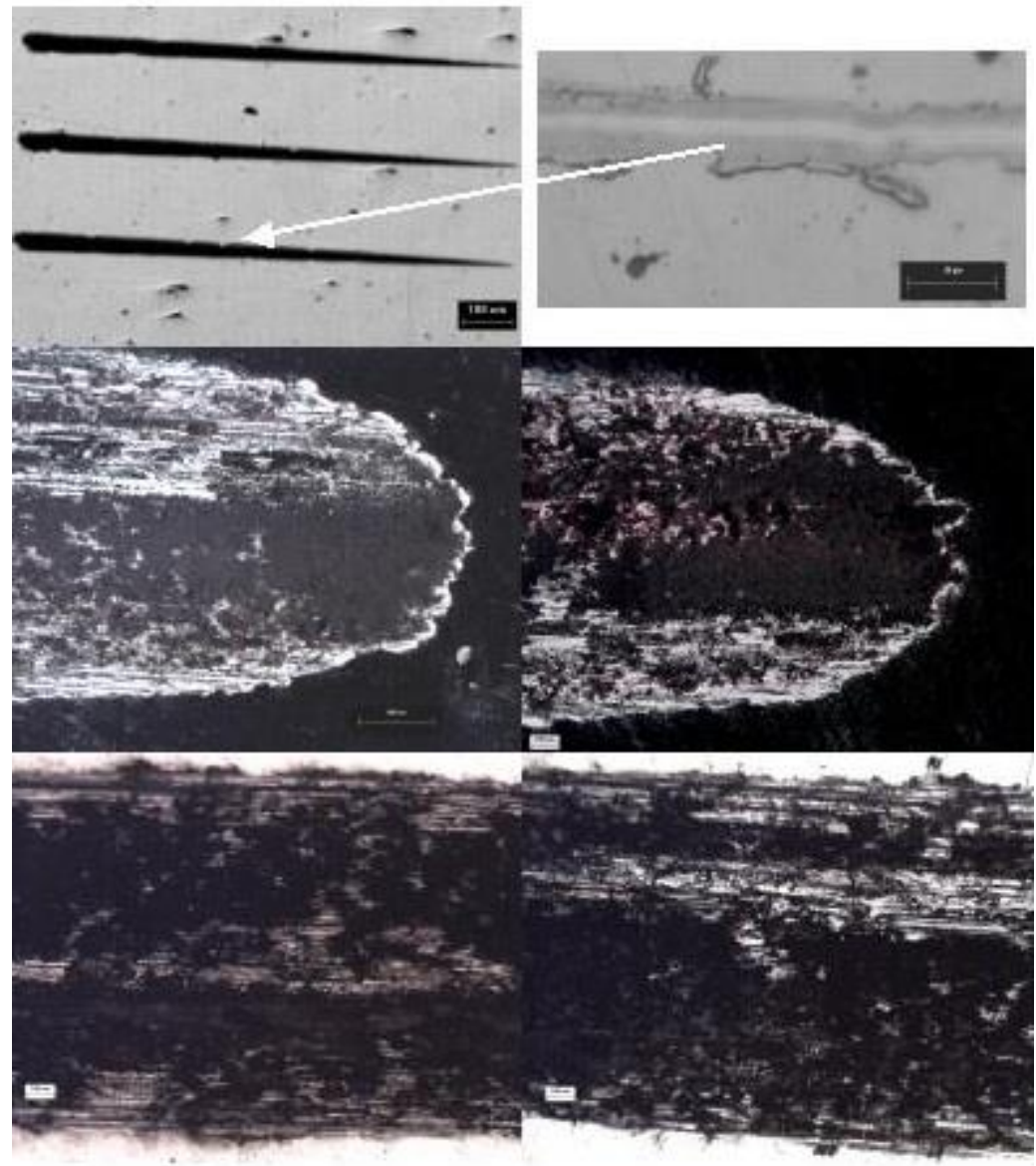

Figure 6: Tribology test [11]: (a) sample A optical microscopy, general view of scratches, (b) enlarged region - scratch center - sample A (c) SEM - end region - sample A, (d) SEM - sample B, (e) SEM - central region - sample A, (f) SEM - central region - sample B.

\section{CONCLUSIONS}

Samples analyzed through XRD - Rietveld Refinement indicated that the presence of a phase $\sigma$ in the sample treated at $1240^{\circ} \mathrm{C}$ provoked an alteration (around 9\%) in the superficial hardness when compared to the sample treated at $1200^{\circ} \mathrm{C}$. At higher penetration depths (bulk), samples presented hardness values very close to one another. Rietveld refinement data indicated that the base structure (austenite) had a volume of unit cell of $46.31(\AA)^{3}$ to $46.33(\AA)^{3}$ for sample A and sample B. This difference is within the margin of error indicated the presence of phase sigma in the sample treated at $1240^{\circ} \mathrm{C}$ did not alter the mechanical properties of the 
BORGES, F. C. N.; OLIVEIRA, W. R.; KUBLITSKI, J. revista Matéria, v.20, n.1, pp. 160 - 168, 2015.

samples studied. The nanoscratch tests did not detect significant influence due to the presence of phase $\sigma$. Regarding friction coefficient, a difference of 5\% was observed when samples A and B are compared.

Finally, it was concluded that the presence of the phase $\sigma$ after the solubilization thermal treatment does not affect mechanical properties (hardness, elastic modulus and friction coefficient) in regions close to the surface. These results are related to the fact that there was no significant structural change (cell volume), below $2 \%$.

\section{ACKNOWLEDGEMENT}

To CNPq, Prof. Dr. Carlos M. Lepienski (Depto. de Física-UPFR), Prof. Dr. Carlos J. de M. Siqueira (Depto. de Eng. Mecânica-UFPR) and Prof. Dr. Paulo R Mei, (Unicamp).

\section{BIBLIOGRAPHY}

[1] FRANSON, I. A., GRUBB, J. F. "Superaustenitic stainless steels", Practical Handbook of stainless steels \& nickel alloys”, ASM International, Materials Park, OH, USA, pp. 243-285, 2000.

[2] DAVIS J. R. “ASM Specialty Handbook Stainless Steels”, ASM International, Materials, Park, OH, USA, 1994.

[3] PADILHA, A. F., PLAUT, R. L., RIOS, P. R. "Stainless steels heat treatment” , In: Totten GE (editor), "Steel heat treatment handbook", 2 ed., Boca Raton (FL, USA), CRC Press, pp. 695-739, 2007.

[4] PLAUT, R. L., HERRENA, C., ESCRIBA, D. M. "A Short review on wrought austenitic stainless steels at high temperatures: processing, microstructure, properties and performance", Materials Research, v.10, n. 4, pp.453-460, 2007.

[5] KOUTSOUKIS, T., REDJAÏMIA, A., FOURLARIS, G. "Phase transformations and mechanical properties in heat treated superaustenitic stainless steels", Materials Science and Engineering A, v. 561, pp. $477-$ 485.

[6] ANBURAJ, J., MOHAMED, S.S., NAZIRUDEEN, R., et al., “Ageing of forged superauastenitic stainless steel: precipitate phases and mechanical properties", Materials Science and Engineering A, v.535, pp. 99- 107, 2012.

[7] NATHANIEL, S. L., PHILliPS, L., CHUMBLEY, L. S., et al., "Phase transformations in cast superaustenitic stainless steels", Journal of materials engineering and performance, v. 18, pp. 1285-1293, 2009.

[8] RITONI, M., MARTINS, M., MEI, P. R. "Efeito do tratamento térmico de solubilização na microestrutura e propriedades de impacto do aço inoxidável superaustenítico ASTM A 744 Gr. CN3MN", Revista Escola de Minas, v. 63, n. 1, pp. 13-20, 2010.

[9] RITONI, M., MEI, P. R., MARTINS, M. "Efeito do tratamento térmico de envelhecimento na microestrutura e nas propriedades mecanicas de um aço inoxidável superaustenitico ASTM A 744 Gr. CN3MN", Revista Escola de Minas, v. 60, n. 1, pp. 155-161, 2007.

[10] RITONI, M., MARTINS, M., NASCIMENTO, F.C., et al., Phase transformations on ASTM A 744 Gr. CN3MN superaustenitic stainless steel after heat treatment, Defect and Diffusion Forum, v. 312-315, pp. 5663, 2011.

[11] NASCIMENTO, F. C., MEI, P. R. "Caracterização das propriedades estruturais, mecânicas e tribológicas do aço superaustenítico ASTM A 744Gr.CN3Mn”, In: XI Seminário Brasileiro do Aço Inoxidável, São Paulo, pp. 1-10, 2012.

[12] NASCIMENTO, F. C., LEPIENSKI, C. M., FOERSTER, C. E., et al., "Structural, mechanical and tribological of AISI 304 and AISI 316L steels submitted to nitrogen-carbon glow discharge", Journal of Materials Science, v. 44, pp. 1045-1053, 2009.

[13] LEPIENSKI, C. M., FOERSTER, C. E. Nanomechanical properties by nanoindentation. In: Hari Singh Nalwa. (Org.). Encyclopedia of Nanoscience and Nanotechnology, Stevenson Ranch: American Scientific Publishers, v. 7, pp. 1-20, 2004.

[14] Alloy phase diagrams, ASM-HANDBOOK, v. 3, 1995.

[15] LEPIENSKI, C. M., NASCIMENTO, F.C., FOERSTER, C. E., et al., "Glow discharge nitriding in AISI 304 at different nitrogen-hydrogen atmospheres: Structural, mechanical and tribological properties", Materials Science and Engineering A, v. 489, pp. 201-206, 2008. 
[16] NASCIMENTO F.C., FOERESTER C. E., LEPIENSKI, et al., "Structural, mechanical and tribological properties of AISI 304 and AISI 316L steels submitted to nitrogen carbon glow discharge", Journal of Materials Science, v. 44, pp.1045-1053, 2009.

[17] TSCHIPTSCHI, A. Paulo., PINEDO C. E. "Estrutura e propriedades do aço inoxidável austenítico AISI 316L Grau ASTM F138 nitretado sob plasma à baixa temperatura”, Revista Escola de Minas, v. 63 n.1, pp.137-141, 2010. 